\title{
The protective performance of selected UK police body armor challenged by M75 grenades
}

Authors :

\author{
Keith Cahill ${ }^{1}$ \\ Michael Booth ${ }^{1}$ \\ Jamie Mercer $^{1}$ \\ Anmar Sabha ${ }^{1}$ \\ Debra Carr ${ }^{2}$ \\ Christopher Malbon ${ }^{3 \text { (now 2) }}$
}

\begin{abstract}
UK Police 'soft' body armor is designed to provide protection from sharp-weapons and low-velocity pistol ammunition; if 'hard' armor plates are fitted then high-velocity rifle protection is provided. Several different levels of protection for both soft and hard armor are available and these are tailored to the individual police officers' role. The level of protection offered by these types of armor from fragmentation threats is not known as fragmentation is not typically considered a threat to UK Police Officers. However, fragmentation from devices such as grenades may be a threat to certain specialized units and during terrorist incidents. In this work, neither the soft nor hard UK Police body armor (HG2 and RF1 respectively) investigated were perforated when challenged by M75 Yugoslavian grenades at a distance of $1 \mathrm{~m}$ from the point of detonation. The effect due to blast was not considered. The work has provided confidence regarding the performance of selected police body armor against fragmentation from a selected grenade threat.
\end{abstract}

\section{INTRODUCTION}

UK Police 'soft' body armor is designed to provide protection from sharpweapons and low-velocity pistol ammunition; if 'hard' armor plates are fitted then high-velocity rifle protection is provided $[1,2]$. Several different levels of protection for both soft and hard armor are available and these are tailored to the individual Police Officers' role [2]. Police body armor in the UK is not designed to provide protection from fragmentation as this is not considered a threat to UK Police Officers.

\footnotetext{
${ }^{1}$ Ammunition Technical Officer Course, Technology School, Defence Academy of the United Kingdom, Shrivenham, SN6 8LA, UK.

${ }^{2}$ Impact and Armour Group, Centre for Defence Engineering, Cranfield University, Defence Academy of the United Kingdom, Shrivenham, SN6 8LA, UK.

${ }^{3}$ Home Office Science, Centre for Applied Science and Technology, Sandridge, St Albans, AL4 9HQ, UK.
} 
In the UK, there has been an increasing awareness that Police Officers may be threatened with hand grenades. In 2012, two Police Officers were killed in an attack that included a M75 Yugoslavian grenade [3]. In an incident which has a reported threat of hand grenades Authorised Firearms Officers (AFOs), Specialist Firearms Officers (SFOs) and Counter Terrorist SFOs (CTSFOs) might attend; these Police Officers have been trained to different levels to specifically deal with incidents involving firearms and those that might be considered to include threats that are military in nature.

Grenades are "a self-contained fragmenting, blast, smoke or gas munition used at short ranges, either thrown or projected" [4]. They come in many different shapes and sizes for a variety of purposes e.g. anti-personnel, anti-armor, smoke for screening and signaling, irritant chemical for riot control and stun grenades for counter-terrorist operations [4]. The type of grenade considered in this project (the M75) is an antipersonnel fragmentation grenade containing 30-35 g of explosive and approximately 3000 ball bearings (Figure 1).

Information regarding the effectiveness of grenades in the peer-reviewed open literature is sparse. What is clear is that grenades result in casualties (fatalities and survivors) on the battlefield e.g. [5]. The immediate threat posed to personnel from grenades is from both blast and fragmentation. Anecdotal evidence suggests that the lethal blast radius from a typical hand grenade is between $1 \mathrm{~m}$ to $5 \mathrm{~m}$. In this work the effects of blast were not considered.

The Home Office Centre for Applied Science and Technology (HOCAST) asked Cranfield University and The Defence Academy of the United Kingdom to investigate the fragmentation protection offered by selected police body armor when challenged with the type of grenade used the incident that occurred in 2012.

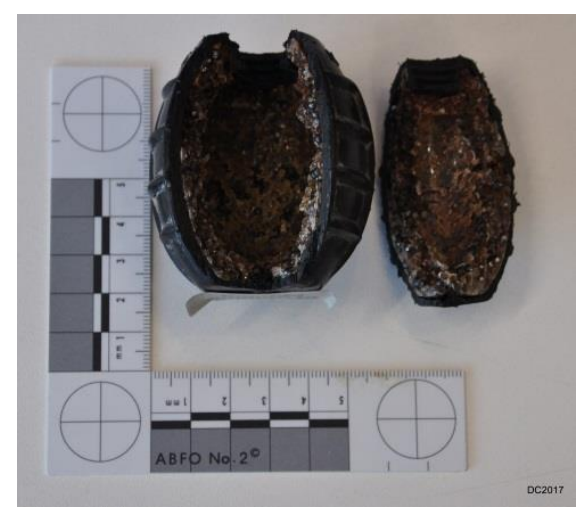

Figure 1. M75 Yugoslavian grenade. 


\section{MATERIALS AND METHODS}

\section{Armour}

In this work, the performance of i) panels $(250 \mathrm{~mm} \times 250 \mathrm{~mm})$ representative of HG2 body armor and ii) RF1 plates was considered ${ }^{1}$ (Table I).

TABLE I. PROTECTIVE PERFORMANCE REQUIREMENTS FOR HG2 AND RF1 ARMOUR [2].

\begin{tabular}{|ll|}
\hline Armour type & Performance requirement \\
HG2 soft armor & 9mm calibre, 9mm FMJ Dynamit Nobel DM11 A1B2, 8.0 g projectile, 430 \pm 10 \\
& m/s impact velocity, UPL* $=25 \mathrm{~mm}$ \\
& $0.357^{\prime \prime}$ Magnum, Soft Point Flat Nose Remington R357M3, $10.2 \mathrm{~g}$ projectile, \\
& $455 \pm 10 \mathrm{~m} / \mathrm{s}$ impact velocity, UPL* $=25 \mathrm{~mm}$ \\
RF1plate & Rifle 7.62mm calibre, 1 in 12" twist, BAE Systems Royal Ordnance Defence \\
& Radway Green, NATO Ball L2 A2, 9.3 g projectile, $830 \pm 15 \mathrm{~m} / \mathrm{s}$ impact \\
& velocity, UPL* $=25 \mathrm{~mm}$
\end{tabular}

* UPL $=$ "The upper prediction limit is a prediction of the likely maximum Back Face Signature (BFS) that would be seen over many hits, based upon the measurements obtained from the limited numbers of test samples" [2].

\section{Grenades}

M75 Yugoslavian grenades were mounted $400 \mathrm{~mm}$ above the containment building floor on wooden posts to minimize contamination. The grenades were prepared by unscrewing the initiators and inserting a standard electric detonator $(1 \mathrm{~g}$ PATN) into the fuze well. The detonator was connected to a SHRIKE which was charged immediately before firing. All grenades were initiated remotely and the products of detonation were allowed to clear before the containment building was entered.

\section{Capturing the grenade fragments}

A recognized method of fragmentation capture during arena trials is to use packs (typically 20-layers) of $3 \mathrm{~mm}$ strawboard located at fixed distances from the point of detonation [6]. Strawboard packs were placed at $1.4 \mathrm{~m}$ and $2 \mathrm{~m}$ from the point of detonation in the current work (distances were dictated by the size of the containment building used). After detonation, each pack of strawboard was taken apart sheet by sheet and the fragments examined for damage as it is recognized that impact into strawboard can damage fragments collected during arena trials [7, 8]. The depth of penetration (DoP) and mass of each fragment was recorded.

\section{Grenade fragment properties}

Five grenade fragments were mounted in epoxy resin, ground and polished to allow the Vickers hardness and the elemental composition (SEM-EDS) to be determined.

\footnotetext{
${ }^{1}$ Neither the manufacturer of the HG2 nor the RF1 armour can be identified at the request of HOCAST, however, both armours are used by UK Police Forces.
} 
The velocity of the fragments from the grenade was determined by inserting captured fragments into sabots and $5.56 \mathrm{~mm}$ NATO cartridge cases and firing at varying velocities (VihtaVouri Smokeless Powder N330) using a number 3 proof housing fitted with an appropriate barrel into strawboard packs until the same DoP was achieved as observed during the arena trials [9]. Velocity was measured using a Doppler radar.

\section{Protective performance of HG2 and RF1 armor challenged by M75 grenades}

HG2 panels (250 $\mathrm{mm} \times 250 \mathrm{~mm}$ ) fixed to the front of strawboard packs and $\mathrm{RF} 1$ plates were placed $1 \mathrm{~m}$ from the grenade to ascertain the fragment protective performance of the armor. Whether or not the HG2 panels and RF1 plates were perforated by grenade fragments was noted.

\section{$1.1 \mathrm{~g}$ chisel nosed fragment simulating projectile (CNFSP) $V_{50}$ data for HG2 armor}

1.1g CNFSP $\mathrm{V}_{50}$ data were determined for the $\mathrm{HG} 2$ armor to allow for future comparison of the current police armor to other armor that provides protection from fragmentation threats [9].

\section{RESULTS AND DISCUSSION}

\section{Grenade fragments}

The performance of M75 grenades does not appear to have previously been reported. A typical strawboard panel post-detonation is shown in Figure 2. Two hundred and sixteen M75 grenade fragments (ball bearings) were recovered from the strawboard packs. The ball bearings were not damaged by the strawboard. The ball bearing mean diameter was $2.65 \mathrm{~mm}(\mathrm{n}=216$, s.d. $=0.04 \mathrm{~mm})$ with a mean mass of $0.07 \mathrm{~g}(\mathrm{n}=216$, s.d. $=0.01 \mathrm{~g})$ (Figure 3$)$. At $1.4 \mathrm{~m}$ from the detonation point the median penetration of the M75 grenade fragments into the strawboard packs was 6layers and at $2 \mathrm{~m}$ the median penetration was 4-layers of strawboard (Table II). The maximum number of layers of strawboard penetrated by the fragments from the M75 grenade was 8-layers (at $1.4 \mathrm{~m}$ ). Subsequent testing conducting by firing M75 ball bearings mounted in sabots and 5.56mm NATO cartridge cases using a proof housing suggested that the ball bearings had a mean impact velocity onto a strawboard pack of $680 \mathrm{~m} / \mathrm{s}$ to penetrate 8 -layers of strawboard $(\mathrm{n}=5$, s.d. $=38 \mathrm{~m} / \mathrm{s})$.

The M75 ball bearings were a high carbon steel, with trace elements of manganese and silicon. The mean Vickers hardness was $654 \mathrm{Hv}(\mathrm{n}=5$; s.d. $=65 \mathrm{Hv})$. 


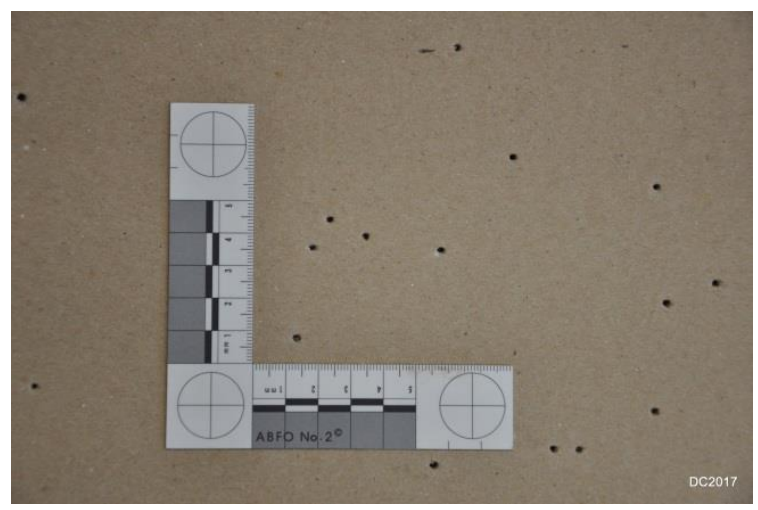

Figure 2. Typical strawboard (first layer, $1.4 \mathrm{~m}$ ) after detonation of a M75 grenade.

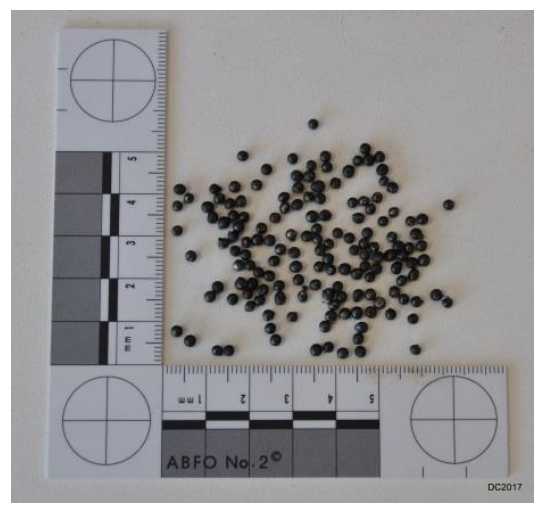

Figure 2. Typical examples of the ball bearings recovered from the M75 Yugoslavian grenades.

TABLE II. PENETRATION OF M75 BALL BEARINGS INTO STRAWBOARD

\begin{tabular}{|ccccccc|}
\hline Distance & \multicolumn{7}{c|}{ Number of layers } \\
$(\mathbf{m})$ & $\mathbf{3}$ & $\mathbf{4}$ & $\mathbf{5}$ & $\mathbf{6}$ & $\mathbf{7}$ & $\mathbf{8}$ \\
1.4 & - & 6 & 16 & 46 & 28 & 3 \\
2.0 & 7 & 45 & 36 & 24 & 5 & - \\
\hline
\end{tabular}

\section{Protective performance of HG2 and RF1 armor challenged by M75 grenade fragments}

Neither HG2 soft armor nor RF1 plates were perforated by M75 grenade fragments at a distance of $1 \mathrm{~m}$ from the point of detonation. This suggested a Police Officer wearing HG2 / RF1 armor should have confidence in the protective capability of the armor system when challenged with fragments from a M75 grenade at a close range.

M75 ball bearings fired using a proof housing at a mean impact velocity of $721 \mathrm{~m} / \mathrm{s}$ did not perforate HG2 armor $(\mathrm{n}=5$, s.d. $=24 \mathrm{~m} / \mathrm{s})$ confirming the performance of the HG2 armor when placed $1 \mathrm{~m}$ from a detonating grenade. Data for M75 ball bearings was collected to allow a single $V_{50}$ to be calculated: $861 \mathrm{~m} / \mathrm{s}$.

\section{$1.1 \mathrm{~g} \mathrm{CNFSP} \mathrm{V}_{50}$ data for HG2 armor}


A single 1.1g CNFSP $\mathrm{V}_{50}$ was calculated for the HG2 armor: $606 \mathrm{~m} / \mathrm{s}$. This performance was comparable to modern military soft body armors which are optimized for protection from fragmentation.

\section{CONCLUSIONS}

There are two main conclusions to be made from this work:

i) The HG2 and RF1 body armor tested (which is one of those used by UK Police Officers) provided protection from M75 fragmentation at $1 \mathrm{~m}$.

ii) The HG2 armor tested offered comparable fragmentation protection to military soft fabric body armors.

However, it should be noted that this study did not consider the effect of blast, considered one type of grenade which contains a relatively low mass of inefficient explosive and only considered one type of HG2 and RF1 body armor.

\section{ACKNOWLEDGEMENTS}

HOCAST for suggesting this project and supplying the armor tested.

WO1 Grice (Technology School, Defence Academy of the United Kingdom) for preparing and initiating the grenades.

Mrs Lankester (Cranfield University) for assistance with determination of grenade fragment velocity and $\mathrm{V}_{50}$ data for $\mathrm{HG} 2$ armor.

Mr Mustey and Dr Painter (Cranfield University) for assistance with measurement of Vickers Hardness and determination of elemental composition of the grenade fragments.

\section{REFERENCES}

1. Lewis, E.A., C. Malbon, J. Breeze, and D.J. Carr. 2017. "Chapter 4 Personal Armour used by UK Armed Forces and UK Police Forces," in Ballistic Trauma ( $4^{\text {th }}$ edition), J. Breeze, J. PennBarwell, D. Keene, and P.F. Mahoney, eds. Springer International Publishing Switzerland.

2. Croft, J., and D. Longhurst. 2007. "HOSDB Body Armour Standards for UK Police. Part 2: Ballistic Resistance Publication No. 39/07/B," Sandridge, St Albans, Home Office Scientific Development Branch.

3. http://www.bbc.co.uk/news/uk-england-19635239 [accessed 15/04/2017].

4. Courtney-Green, P. R. 1990. Ammunition for the Land Battle (Land Warfare). Brassey's UK Ltd.

5. Carr, D.J., E.A. Lewis, and I. Horsfall. 2017. "A Systematic Review of Military Head Injuries," $J$ Roy Army Med Corps., 163:13-19.

6. Ministry of Defence. 2005. "Defence Standard 93-95 Chipboard (For Use at Proof and Experimental Establishments)," Glasgow, Defence Procurement Agency.

7. Fragmentation Panel. 1945. Investigation of Break-up of Fragments During Penetration into Strawboard Targets. WO 195/8760.

8. Cant, D.S., A. Ashmore, J. Dray, D.J.L. McKay, C. Saunders, E.A. Lewis, D. Miller, M. Teagle, and D.J. Carr. "A Comparison of Fragment Simulating Projectiles and Real Fragments with Respect to Soft Body Armour Performance," in International Symposium on Ballistics, May 9-13, 2016. Edinburgh, UK.

9. NATO. 2015. "AEP 2920 Procedures for the Evaluation and Classification of Personal Armour: Bullet and Fragmentation Threats," NATO Standardization Office. 